\title{
Hvad kan lokalarkiver og foreningsarkiver bruges til?
}

\author{
af Verner Bruhn
}

\section{Lokale arkiver og indsamlinger}

De sidste 20 år er der sket en sådan vækst i antallet af lokalhistoriske arkiver at omkring $96 \%$ af vore kommuner er dækket med et eller flere lokalarkiver, og arkivernes organisation Sammenslutningen af Lokalhistoriske Arkiver (SLA) kan registrere et medlemstal på nær 350.' Dette umiddelbart imponerende tal dækker imidlertid over store forskelle: mange arkiver er små lokalsamlinger, andre store med veludbyggede arkivrum, læsesale m.v., mange drives alene med frivillig arbejdskraft der kan være begrænset til en enkelt aften om ugen i vintersæsonen, andre er ledet af faguddannede; heltidsansatte arkivfolk. Det betyder naturligvis at der er stor forskel på hvad det enkelte lokalarkiv har kunnet magte at samle ind, haft tid og ressourcer til at registrere og hvilken grad af tilgængelighed arkivet kan tilbyde. Det er derfor vanskeligt at sige noget generelt om hvad det enkelte arakiv kan yde af hjælp til den forsker der henvender sig. På den anden side er det klart at et lokalhistorisk arbejde ikke kan begynde uden at der tages kontakt til arkivet. Hvad der ikke ligger på arkivet kan måske med støtte fra dette opspores i lokalsamfundet.

De seneste år har mange arkiver imidlertid været involveret i et indsamlingsarbejde som har den største interesse netop for idrætshistorie. I en række amter er der gennemført såkaldte ,foreningskampagner" hvor der gennem en samlet indsats og med professionel bistand er registreret og indsamlet foreningsarkiver af enhver slags. Det betyder at der for ca. halvdelen af danske amter foreligger en registrant, hvori man let kan se $i$ hvilken udstrækning materiale fra idrætsforeninger er optegnet, hvor omfattende dette materiale er og hvor det befinder sig. Ikke alle foreningsarkiver er nemlig afleveret, selv om de er registreret, men blot det at vide hvor de befinder sig er en hjælp. Den sidste foreningsregistrant der er udkommet

1. Oplysninger om de enkelte arkiver kan fås hos SLA hvis sekretariat findes på Lokalhistorisk arkiv for Aalborg kommune, Peder Barkesgade 5, postboks 1353, 9100 Aalborg. 


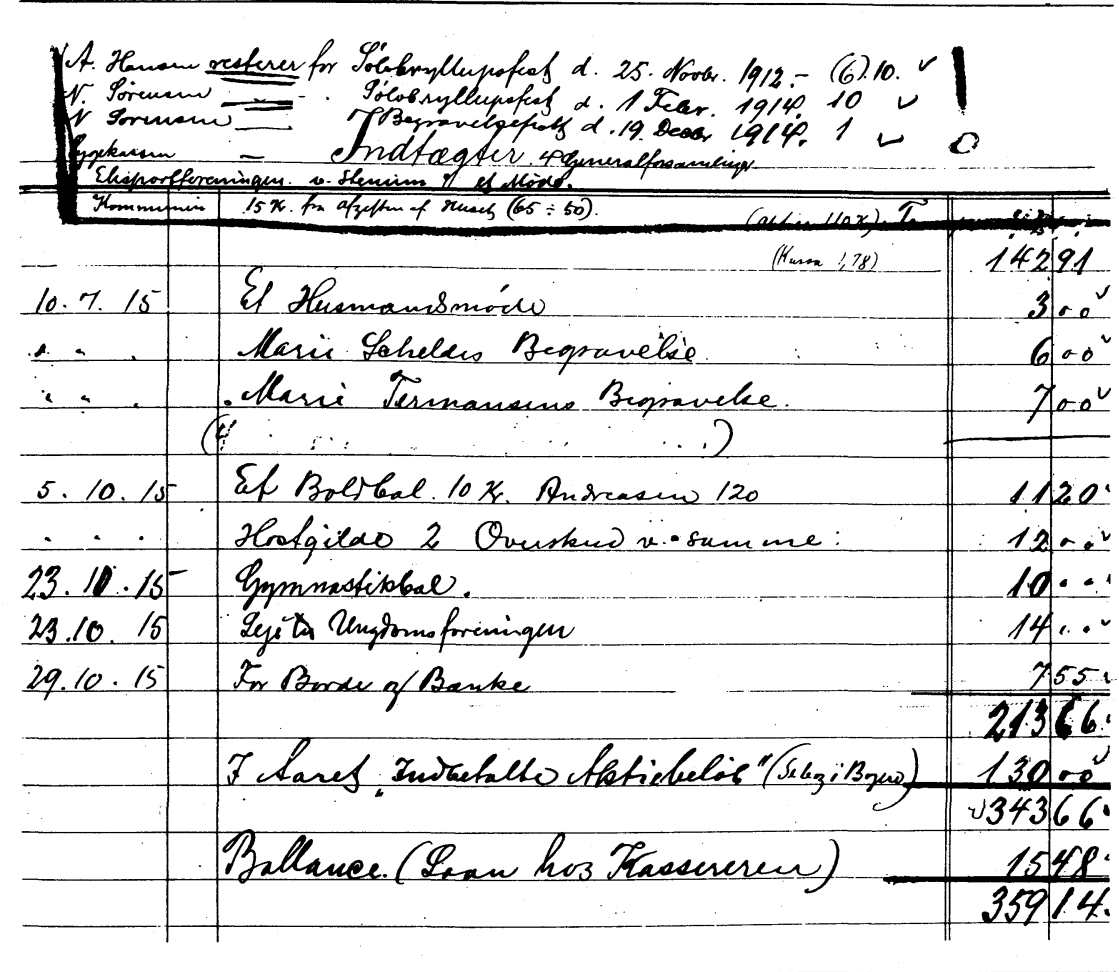

Side af regnskabsbog for Læborg forsamlingshus, omtalt i teksten. „Et Boldbal" er nævnt 5.10. (Privateje).

dækker indsamlingen i Ribe amt og er et værk på knap 1000 sider, omfattende op imod 3000 foreninger af enhver slags. ${ }^{2}$

Samlet ind, men ikke brugt ...

Man kan trods det lokale arkivwæsens store forskelligheder sige at der er gennemført et solidt indsamlingsarbejde og et stort registreringsarbejde. Der ligger i dag i tusindvis af protokoller, regnskabsbøger m.m. på danske

2. Foreninger i Ribe amt, en arkivregistratur, 960 s., 1985, i kommission hos Historisk Samfund for Ribe Amt. 
Ordensregler har altid været et ømt punkt i foreningerne. Disse fortæller om bondesamfundets karlekammermiljø. De stammer fra en foreningsprotokol 1923.
"Gymnastikken skal

vxere præget af Ro, Or.

den og Disciplin ... For

Spytning, Færdsel med

Træfodtøj på Gulvet

samt Tobaksrygning i

Salen erlægges 1

Krone"

lokalarkiver. Til gengæld må man sige at der ikke har været tid og kræfter til at bruge materialet. I betragtning af at idrætsforeningerne har udgjort et meget stort område af dansk foreningsliv $i$ det hele taget og vel nok haft de største medlemstal, så er undersøgelser og publiceringer af lokale foreninger og deres arbejde, betydning og indsats et forsømt område. Hvor forsømt kan ses i Else Trangbæks bibliografi over dansk idrætshistorie. ${ }^{3}$

Der findes naturligvis et utal af lokale jubilæumsskrifter, og selv om de kan rumme værdifuldt stof så er de gennemgående af ,,hurra-kategorien“. Det vil sige at de kredser om foreningen som et lukket miljø, og deres formål er at hædre foreningens pionerer, formænd og andre frontfigurer, derimod ikke at sætte foreningen ind $i$ en større, lokal eller samfundsmæssig sammenhæng. De fleste jubilæumsskrifter er bygget på erindringsstof og i bedste fald tilfældige udpluk af forhandlingsprotokoller, hvis de er bevaret. De er sjældent skrevet af en historiker, oftest af en tidligere formand eller kasserer, og selv om denne sikkert var en god formand siger det jo ikke noget om hans kvalitet som historieskriver.

Arkiverne har som nævnt samlet mængder af arkivstof ind, og det er vigtigt at det nu bliver benyttet til en række lokalanalyser og beskrivelser af idrættens betydning.

\section{Det lokale arkivstofs begrænsninger}

De lokale foreningers materiale er kun delvis bevaret, dvs. dele af det er helt forsvundet, for nogle foreninger findes f.eks. regnskabsprotokol, men ikke forhandlingsprotokol, for andre er der bevaret medlemsfortegnelser for nogle år, ikke for andre osv. osv. Denne mangel ved det lokale arkiv deler

3. Se Idrætshistorisk Årbog 1985, nr. 1 side $203 \mathrm{ff}$. 
idrætshistorikeren med andre kolleger, men det nævnes fordi det må appellere til historikerens evne til at kombinere: hvad kan hjælpe mig videre når det primære materiale svigter. Blot et enkelt eksempel på banal karakter: Jeg manglede oprettelsesår for en boldklub $i$ et vestjysk sogn og de ældste protokoller var borte. Et bevaret billede tydede på at foreningen eksisterede omkring 1920, og en eftersøgning i det lokale forsamlingshus-regnskab viste at der i 1915 var blevet afholdt ,et boldbal". Min tolkning var at det var et bal afholdt af „,boldklubben“, jvf. et skyttebal, et gymnastikbal. Dvs. at forsamlingshusets regnskab hjalp mig tilbage til 1915. Sådanne kombinationer mellem forskelligt kildemateriale må man gang efter gang ty til, og tit kan det være helt utraditionelle kombinationer der hjælper én på gled.

Men det ufuldstændige materiale er kun en af de vanskeligheder et lokalt foreningsarkiv kan byde på. Selv om en forenings arkiv foreligger intakt er der andre forhold historikeren må være opmærksom på - to skal nævnes her.

Den ene er, at en forhandlingsprotokol er blevet ført af skiftende sekretærer, nogle har siddet længe, andre kort.

Der foreligger ingen fast procedure for hvordan en forhandlingsprotokol skulle føres, ingen retningslinjer og - $i$ hvert fald for ældre tid - ingen indberetningspligt til en overordnet organisation. Det betyder at det er ganske tilfældigt hvad en sekretær har taget med $i$ referater af møder, generalforsamlinger osv. Nogle skrev meget, ofte blomstrende, medens andre har noteret så kortfattet at det tit er vanskeligt at vurdere om det centrale overhovedet er med. Man kan ærgre sig over at sidde med mangelfulde oplysninger, på den anden side er der ofte mere liv over disse ældre protokoller end over nyere duplikerede referater hvis væsentligste indhold er turneringsplaner!

Det andet forhold en historiker må gøre sig klart når han eller hun sidder med en forenings forhandlingsprotokol er, at det er bestyre/sens synspunkter der træder frem. Foreningen er set „ovenfra“, fra ledernes side, og det betyder at den indfaldsvinkel der fås gennem protokollen er formandens, kassererens, sekretærens osv., og ofte er det foreningens problemer der fylder mest $i$ referaterne, for det er nu engang ledernes opgave at løse foreningens problemer - økonomiske, idrætslige eller af hvad art de nu kan være. Det er jo ikke sikkert at medlemmernes opfattelse af foreningen var en sådan ,,problemorienteret" “, for dem erindres foreningen måske mest for det glade samvær, men det står ikke i bestyrelsens protokol.

Til en vis grad er regnskaber af samme karakter med forskellige kasserere med forskellige traditioner og mere eller mindre nøjagtige formuleringer. Det betyder ikke at protokoller og regnskaber er dårlige eller tvivisomme kilder alt kildematerale er i princippet godt. Det er historikerens opgave at stille de rigtige spørgsmål til det materiale han eller hun sidder med. 


\begin{tabular}{|c|c|c|c|c|c|c|c|c|c|}
\hline \multirow[t]{4}{*}{ Vracegning } & \multirow{2}{*}{ 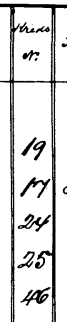 } & \multirow{2}{*}{ 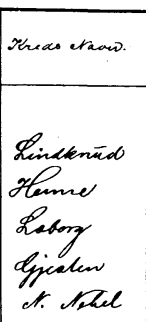 } & \multirow{2}{*}{ 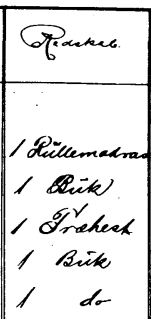 } & \multirow{2}{*}{ 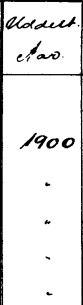 } & \multirow[b]{2}{*}{$\begin{array}{l}\text { Parcei. } \\
25 . \\
\\
24 \\
20 \\
750 \\
20 \\
30\end{array}$} & \multicolumn{3}{|c|}{$\begin{array}{c}\text { 'tranag. } \\
\text { xe? }\end{array}$} & \\
\hline & & & & & & $\begin{array}{c}900 \\
2 \\
20 \\
20 \\
20 \\
20 \\
20\end{array}$ & \begin{tabular}{c|}
1901 \\
7 \\
10 \\
16 \\
10 \\
10
\end{tabular} & 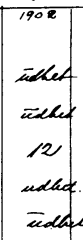 & $\begin{array}{l}1903 . \\
- \\
27 \text { sache } \\
\text { C. }\end{array}$ \\
\hline & $\begin{array}{l}20 \\
26 \\
35 \\
25\end{array}$ & 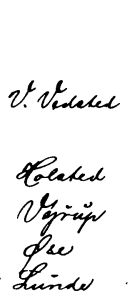 & 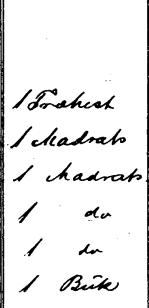 & 1901 & $\begin{array}{l}80 \\
132 \\
24 \\
24 \\
38.50 \\
30 .\end{array}$ & $\begin{array}{l}1901 \\
22 \\
20 \\
16 \\
16 \\
20\end{array}$ & \begin{tabular}{r|}
1900 \\
50 \\
4 \\
8 \\
14 \\
10
\end{tabular} & $\begin{array}{l}1900 \\
24 \\
\text { zedhat } \\
\text { acheck } \\
8.50\end{array}$ & 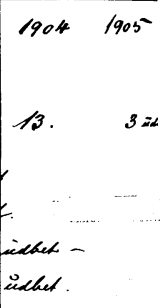 \\
\hline & $\mid$\begin{tabular}{l|}
12 \\
28 \\
31 \\
404 \\
48 \\
52 \\
26
\end{tabular} & 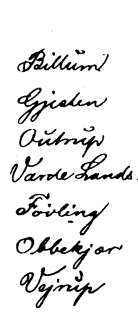 & 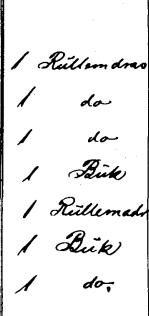 & 1902 & $\begin{array}{l}32 \\
32 \\
32 \\
11 \\
32 \\
30 \\
30\end{array}$ & $\begin{array}{r}1902 \\
92 \\
18 \\
18 \\
10 \\
10 \\
12 \\
12\end{array}$ & $\begin{array}{r}1903 \\
12 \\
12 \\
8 \\
1 \\
12 \\
18 \\
10\end{array}$ & $\begin{array}{c}190 k \\
8 \\
2 \\
6 \\
\text { rach } \\
\text { s. } \\
\text { cicld } \\
8\end{array}$ & 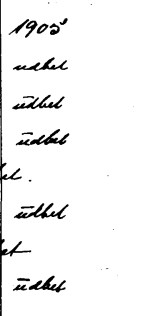 \\
\hline 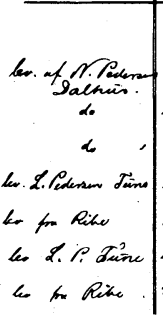 & $\begin{array}{l}8 \\
12 \\
39 \\
40 \\
44 \\
47 \\
54\end{array}$ & 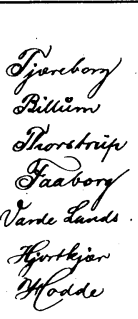 & 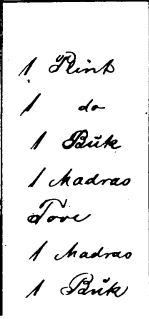 & 1903 & $\begin{array}{l}25^{\circ} \\
25^{\circ} \\
30 \\
32 \\
25^{\circ} \\
32 \\
40\end{array}$ & $\begin{array}{c}1903 \\
12 \\
12 \\
10 \\
11 \\
10 \\
10\end{array}$ & $\begin{array}{l}1904 \\
13 \\
10 \\
18 \\
12 \\
14 \\
20 \\
12\end{array}$ & 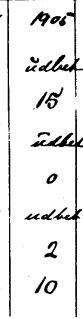 & $\begin{array}{l}1906 . \\
\text { nadect. } \\
10 \text { rathet } \\
\text { molled } \\
8 \text { ichlact. }\end{array}$ \\
\hline
\end{tabular}

Amtsforeningerne forvaltede det statstilskud som skytteforeningerne modtog. Fordelingen på lokalkredse kan være en hjælp til at få oplysninger om aktiviteter ude $i$ sognene. (Fra Ribe amt 1904). 


\section{Varde-Olgod Hovedkreds}

Sommermade ved Lindingbro Søndag den 4. Aug. Kl. 3 med Foredrag af Højskoleforst. Hans Lund, Rødding. Kl. 5 Gymnastikopvisnng paa Idrætspladsen af et Kvinde- og et Mandshold fra Ribe Amts 2. Hovedkreds. Derefter Kaffebord og Liegstow.

P. F. V.

Carl S. A. Hansen.

Idealet om "det hele menneske“

- ånd og legeme - levede længe i

dele af landet. Annoncen er fra 1940.

\section{Lokalarkivets kvaliteter}

Når nu alle de ovennæunte forbehold er taget er det måske på tide at understrege det banale, at det lokale foreningsarkiv - protokoller, regnskaber, programmer, billeder, klubblade osv. - er en guldgrube for idrætshistorikeren. Den lokale forenings eller de lokale foreningers materiale har betydning på to områder: for det første hjælper det til at placere idrætten i lokalsamfundet, for det andet vil det kun gennem en række lokalsamfundsanalyser være muligt at få idrættens betydning beskrevet på landsplan. Begge opgaver er vigtige og begge er spændende at arbejde med og det kan vel ikke skade arbejdet at det både er nyttigt og sjovt.

Det særlige ved de lokale protokoller er jo at de langt bedre end andet materiale afslører idrættens bundethed til lokalmiljøet, man kommer så at sige ned i sognet eller byen. Når der f.eks. i en række gymnastikforeningers protokoller sendes afbud til et amtsstævne $\mathrm{i}$ forsommeren er årsagen ikke nævnt mere end et sted, men den er også dækkende: „Alt for mange medlemmer er i høet". Afbuddene kom fra foreninger i sogne med store engstrækninger og høhøsten var lige så vigtig som kornhøsten. Så enkelt afsløres sammenhængen mellem erhvervsstruktur og idræt og gymnastikforeningerne var jo i udpræget grad landboforeninger. Det samme træk slår igennem $i$ en anden sammenhæng. For nogle år siden prøvede jeg at undersøge hvem der var foreningsledere i gymnastikforeningerne og hvem der blev delingsførere. Der var angivet en række erhverv (lærer, kommis o.a.), spørgsmålet var om alle de navne der var opført uden stillingsbetegnelse var landmænd. En række kontrolopslag i folketællinger bekræftede at det var de, for datidens sekretærer har det været ganske overflødigt at anføre. For os synes det at være en mangel, men i virkeligheden viser det kun hvor tæt bundetheden til det lokale miljø (her erhvervsmiljø) har været.

Min erfaring stammer hovedsagelig fra gymnastik- og ungdomsforenin- 


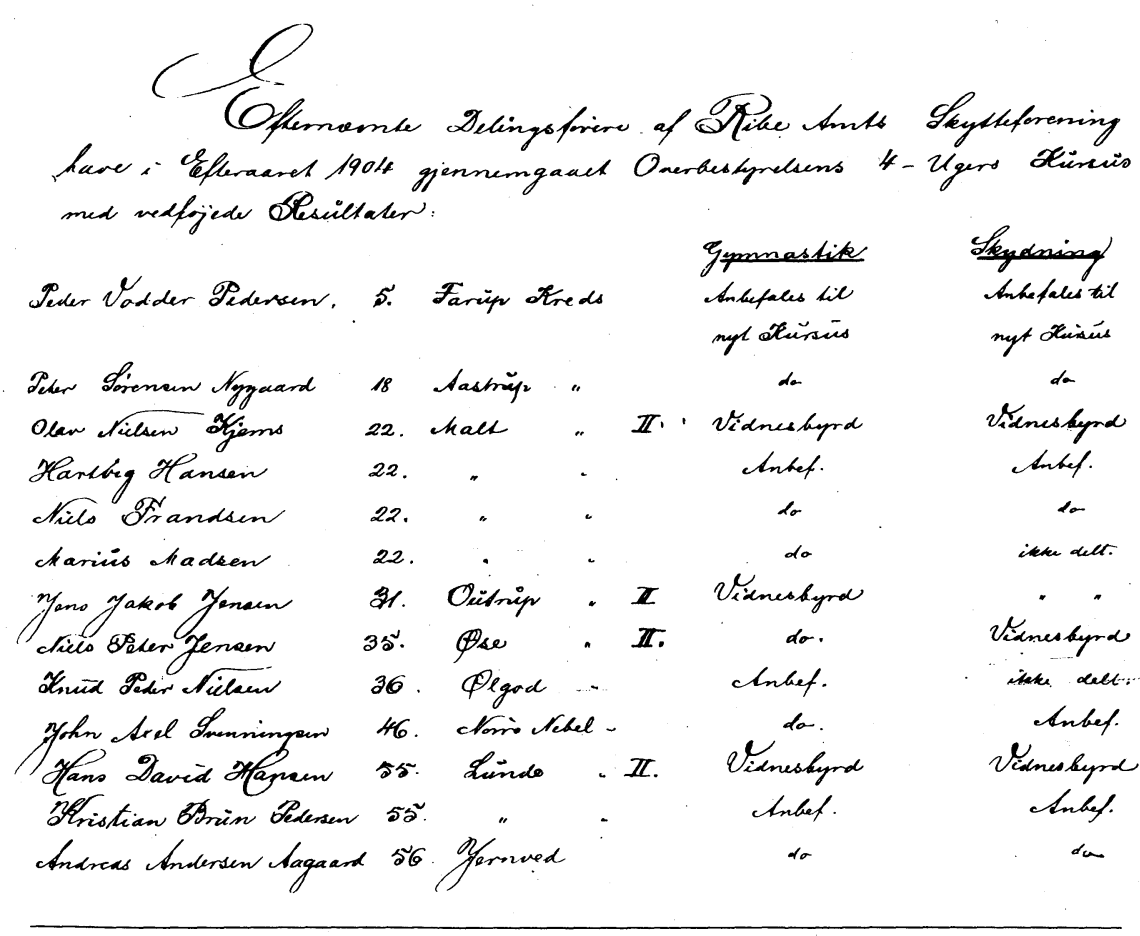

Delingsførernes betydning for det lokale gymnastikliv var meget stor. En del af dem kan findes ved at gennemgå den lokale amtsforenings protokol. (Fra Ribe amt 1904).

gers arkiver i Ribe amt og nogle enkelte byforeningers materiale. ${ }^{4} \mathrm{De}$ vestjyske sognes erhvervsrytme, arbejdsrytme og traditionelle samværsvaner går igen i foreningernes arbejdsmønster. I et par generationer varetog gymnastik- og ungdomsforeningerne stort set det kulturelle fritidstilbud til sognets unge, og derved blev dette arbejde en del af sognets hele liv som herskab, husbond, præst og lærer lagde vægt på, fordi de i datidens patriarkalske samfund også følte sig ansvarlig for de unges fritidssysler - så langt det nu lod sig gøre. Det er ind i en sådan lokalhistorisk, kulturel

4. Fra mit arbejde med bogen Plint og Talerstol - træk af gymnastik- og ungdomsforeningernes historie i Ribe amt. 184 s., ill. 1979. Fra dette arbejde stammer også eksempler og citater $\mathrm{i}$ artiklen. 
sammenhæng at det lokale foreningsarkiv kan hjælpe forskeren, og det er netop vigtigt at få idrætshistorien til at belyse idrættens placering i lokalsamfundets hele. I modsætning til jubilæumsskrifternes lukkede miljø skal de undersøgelser og beskrivelser vi har brug for åbne og være åbne.

På dette sted vil jeg gerne vende tilbage til min tidligere bemærkning om at forskeren må kombinere de forskellige lokale kilder. Det er vigtigt for forståelsen af helheden at placere det idrætslige i sognet i sammenhæng med sognets øvrige foreningsliv. Mange skytte- og gymnastikforeninger havde foredrag tilknyttet som en del af arbejdet ud fra den gamle grundtvigske opfattelse at målet var ,det hele menneske“. Derfor er gymnastik ofte nævnt i forsamlingshusets vedtægter som en af de aktiviteter der skal have husrum der, måske til særlig lav leje, hvis overhovedet nogen. Nogle sogne havde en stærk afholdsbevægelse i tiden før 1914 og nogle steder var der et samarbejde mellem afholdsbevægelse, gymnastikforening - og brugsforening i øvrigt. Hvordan foregik et sådant samarbejde i det lokale miljø? Var der tale om et formaliseret samarbejde nævnt $i$ referater eller måske endog $i$ formålsbestemmelser, eller var der tale om et uformelt samarbejde der væsentligt fungerede ved personsammenfald $i$ bestyrelserne? Sådanne undersøgelser kræver at forskeren kombinerer forskellige lokale foreningers arkiver og at han bruger sin fantasi når han går på jagt efter oplysningerne. Det letteste er at lade en beretning være et kronologisk resumé af forhandlingsprotokollen, men det er ikke den slags der er brug for.

\section{Idræt og politik}

En af de sejlivede myter $i$ vore dage er at idræt og politik ikke har med hinanden at gøre. Trods bevis efter bevis på at det er en myte fastholdes den stadig af mange ledere og en del politikere. Der er ingen tvivl om at skyttebevægelsen og gymnastikforeningerne for 100 år siden var aktivt inddraget $\mathrm{i}$ den politiske strid mellem Højre og Venstre, en strid der var langt mere end en politisk strid om opfattelsen af Grundloven, det var både en social og kulturel konfrontation. Skyttebevægelsen blev efterhånden domineret af Venstre både på landsplan og på lokalplan. Det er sjældent at de lokale foreningsprotokoller afgiver klare vidnesbyrd om denne politiske strid. Det betyder imidlertid ikke at man ikke kan finde ud af hvordan foreningen har stillet sig, det kræver blot igen kombinationsevne og fantasi. Efter regeringsforbuddet mod "riffelforeningerne“ i 1880'erne kan man ved at læse referater $\mathrm{i}$ aviser, foreningsblade $\mathrm{m} . v$. konstatere en ændring $\mathrm{i}$ talerækken. Der taltes meget ved skyttefester(!) for kvinden (som ikke var med), for 
"Det foresloges, at de

unge Kvinder, som øve

Gymnastik i Forsam-

lingshuset for Brugen

af samme for i Vinter

skal give $5 \mathrm{Kr}$. for Lys

og Varme».
"Kathrine Therkildsen,

Ll. Darum, blev æres-

medlem, fordi hun var

den forste gifte kvinde

der indmeldte sig i for

eningen ..."

Den lingske gymnastik var et led i kvindefrigøre/seskampen, og det er derfor væsentligt at finde frem til bl.a. hvornår kvindegymnastikken kom i gang og hvordan holdningen til den var. Citater fra to forhandlingsprotokoller fra to forskellige sogne i Ribe amt, henholdsvis 1889 og 1904.

kongen, for foreningen - men i langt de fleste foreninger blev der ikke talt for regeringen mere. I de foreninger hvor der udbragtes et ,leve for regeringen Estrup" kan man være sikker på at bestyrelsen endnu har Højredominans. 1 nogle foreninger hvor der blev holdt foredrag i forbindelse med fester, kan man også ved at se på emnerne få et indtryk af om foreningen har hørt til de mere progressive eller mere ,neutrale" i deres iver for at vække de unges politiske interesse. Nogle foreninger har emner som „Apostelen Paulus“ „En glad gut", ,Martin Luther“, andre foreninger præsenterer emner som „,Om parlamentarisme“", „Den almindelige valgret", ,Kvindernes stilling i samfundet" . Det siger immervæk en del.

Så mangelfulde lokale foreningsprotokoller end er så giver de muligheder for at komme sognet ind på livet. Sværest er det måske at komme tæt på personer fordi de - dengang - var kendte i det lokale miljø og derfor kun blev ufuldstændig navngivet. Bestyrelsesmedlemmer er oftest angivet ved fornavn og efternavn, men ledere, instruktører og andre er tit blot angivet ved efternavn: „Holm tog gymnastikken med pigerne“ eller „Knudsen skulle bedømme mændene ved amtsstævnet". Det samme gælder i øvrigt foredragsholdere: „Pastor Larsen talte ...“, ,,ærer Madsen sluttede af“. Det kan være svært at identificere personer, også her må man kombinere med andre lokale kilder.

Også på det organisatoriske område skal der kombineres på kryds og tværs. Hovedkredsinddelingen $i$ de forskellige amter var f.eks. i høj grad en praktisk foranstaltning, og i Ribe amt var den væsentlige årsag til ændring $\mathrm{i}$ inddelingen etableringen af lokalbaner, der gav medlemmer let adgang til hovedkredsarrangementer og betød færre transportudgifter til talere og instruktører. Det har også ofte undret mig hvordan tilslutningen til en 
gymnastikforening (eller for så vidt aktietegning til et forsamlingshus) kunne té sig geografisk inden for et sogn. Jeg har ikke endnu arbejdet problemstillingen igennem, men jeg har en svag formodning om at den ofte rettede sig efter-mælkeruterne til det lokale mejeri!

\section{Det lokale og det nationale}

Der er som ovenfor nævnt mange indfaldsvinkler til det lokale stof, men det lokale får sin perspektivering ved at blive set $\mathrm{i}$ forhold til det nationale. Ved at kende landsorganisationen eller hovedorganisationen får man mulighed for at trænge ind i den lokale kreds og måle dens engagement i de landsdækkende problemer og diskussioner. Nogle få eksempler kan vise dette:

Estrupregeringens cirkulære fra 1885 om ,riffelforeningerne" skabte store spændinger i de enkelte amtsskyttekredse. Nogle accepterede at skytteforeningerne skulle ansøge om tilladelse til at skyde, andre nægtede det. Hvordan forholdt de lokale foreninger sig til anbefalingerne fra Overbestyrelsen, drøftede de dem, rettede de sig efter dem, gav hele sagen anledning til strid i lokalforeningen?

I 1914 anbefalede Ribe amt Overbestyrelsen at kvinder fik stemmeret i De danske Skytteforeninger. Det fik kvinderne først i 1918, men i de mellemliggende år var kvindernes valgret på tale flere gange. Gav det sig udslag i lokal debat, findes der synspunkter i de lokale protokoller på dette spørgsmål, er det blevet behandlet på generalforsamlinger, og lidt videre: hvor tidligt optræder der kvinder i den lokale bestyrelse, i amtets bestyrelse?

I 1919 vedtoges det at De danske Skytteforeninger skulle skifte navn til De danske Skytte- og Gymnastikforeninger. Men blev ændringen gennemført lokalt, blev det nye navn brugt i protokollerne, blev det anvendt på trykte programmer? Jeg har i en lokal foreningsprotokol fundet en sekretær som først i 1924 gik over til det nye navn, og tilsyneladende er der ingen der har gjort indsigelse mod hans referater.

I 1929 fandt bruddet mellem skytter og gymnaster som bekendt sted. Gymnasterne meldte sig ud og stiftede De danske Gymnastikforeninger og den gamle skytteforening ændrede navn og blev til DDSG\&I. Striden var gammel mellem de to parter og der indgik mange momenter $\mathrm{i}$ den: striden med Niels Bukh om lederskabet ved landsstævnet i Dybbøl, diskussionen om konkurrencemotivet - ,skytterne med deres teskeer og sølvplader ..." og flere andre faktorer. Blev hele denne problemkreds drøftet lokalt, har den afspejlet sig i referater, i ændring i bestyrelsens sammensætning osv. osv.? Torben Jakobsen har i sit speciale om delingen hævdet at der var et stærkt sammenfald mellem udbryderne fra gymnastikforeningerne og Det radikale 
Udbredelsen af dansk og svensk gymnastik. 1898

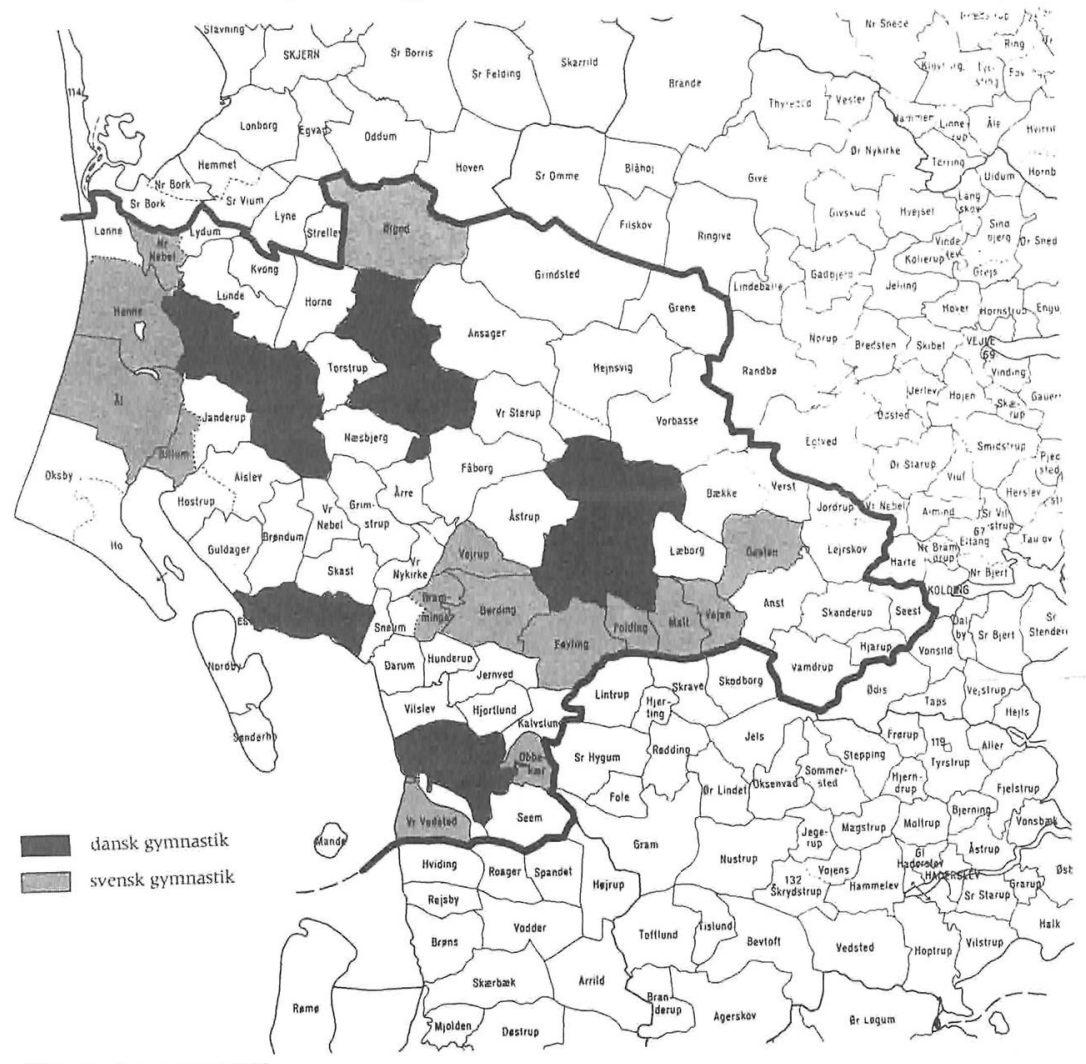

Kilde: Ungdom og Idræet 1898

Striden mellem ,dansk" og „,svensk“ gymnastik og udbredelsen heraf er et vigtigt led i studiet af et lokalområdes idrætshistorie. Dette kort er udarbejdet af forfatteren til bogen Plint og Talerstol, ivf. note 4.

Venstre. ${ }^{5}$ Også den tese er en lokalundersøgelse værd: hvem tog initiativet til delingen, hvem sad $\mathrm{i}$ bestyrelsen $\mathrm{i}$ gymnastikforeningen, $\mathrm{i}$ hvilket omfang var de involveret i politik, her: radikal politik, hvor åbenbar eller skjult var denne forbindelse?

Disse eksempler er tilstrækkelige til at vise hvad jeg mener med at

5. Torben Jakobsen: Legemskultur i mellemkridstiden, speciale ved Århus universitet 1982. Se i øvrigt Idrætshistorisk Årbog 1985, nr. 1 side 125-135. 
perspektivere det lokale på landsplan. Andre eksempler kan let føjes til: stillingtagen til Niels Bukhs ideer om et samlet dansk ungdomsforbund, holdningen til Dansk Ungdoms Samvirke i besættelsesårene, samarbejde eller modsætning til KFUM-arbejdet, lokal vurdering af musik til mandsgymnastik som en lokal gymnastikleder $i$ et sogn i Ribe amt karakteriserede som „,forfald" og ,,pjadderværk".

Ved at gå ind på sådanne diskussionsområder som har spillet en rolle på landsplan kan man få et indtryk af, i hvilket omfang den lokale forening var med eller ikke med i mere principielle drøftelser. Min egen erfaring er at mange foreninger ikke overhovedet har taget stilling - eller rettere: det har ikke sat sig spor $\mathrm{i}$ det bevarede kildemateriale. Enkelte foreninger har $\mathrm{i}$ betydeligt omfang beskæftiget sig med disse mere overordnede sager, og det er - ikke overraskende - sådanne foreninger hvor den lokale formand eller leder samtidig har indtaget en post $\mathrm{i}$ landsforeningen som medlem af bestyrelsen eller af et udvalg e.l.

\section{Afslutning}

Det har været min hensigt med disse sider at pege på en række muligheder $\mathrm{i}$ anvendelse af lokalt foreningsmateriale. Jeg har argumenteret for - og håber at have eksemplificeret det - at materialet giver stort udbytte, hvis forfatteren kombinerer idrætsforeningernes arkiver med andet lokalt materiale. Endvidere har jeg argumenteret for at man forsøger at sætte det lokale foreningsarbejde $\mathrm{i}$ et landsperspektiv ved at gå ind i materialet for at finde holdninger til arbejdet på landsplan.

Idrættens betydning har gennem mere end 100 år været af enorm betydning både idrætsligt og kulturelt og idrætshistorien er en så væsentlig del af vort kulturhistoriske billede, at der er behov for en lang række lokalhistoriske undersøgelser både for lokalhistoriens skyld, men sandelig også for rigshistoriens skyld.

I de lokale arkiver hober materialet sig op takket være en stor arbejdsindsats fra arkivernes side. Nu trænger det til at blive støvet af og brugt i formidlingens tjeneste. 